\title{
Pengembangan E-Modul Dengan Pendekatan STEAM Berbasis Sigil Software Mata Pelajaran Administrasi Sistem Jaringan Kelas XI TKJ
}

\author{
Iskariyana $^{1}$, Puji Rahayu Ningsih ${ }^{2}$ \\ ${ }^{1}$ SMK Al Fattah Kertosono, Nganjuk, Indonesia \\ ${ }^{3}$ Program Studi Pendidikan Informatika, Universitas Trunojoyo Madura, Madura, Indonesia \\ email: ${ }^{1}$ iskariyana98@gmail.com, ${ }^{2}$ puji.ningsih@trunojoyo.ac.id
}

\begin{abstract}
Abstrak
Penggunaan bahan ajar merupakan salah satu faktor penting agar kegiatan pembelajaran dapat berjalan dengan baik. Pendidik dituntut agar dapat melakukan inovasi dalam proses pembelajaran sesuai dengan perkembangan zaman di era industri 4.0. Dalam kegiatan pembelajaran tentu saja membutuhkan bahan ajar sebagai acuan agar pembelajaran dapat berjalan dengan baik. Salah satu permasalahan yang ditemui di SMK Kosgoro Nganjuk adalah belum adanya bahan ajar berupa e-modul dan sulitnya siswa mencari referensi di internet terkait mata pelajaran Administrasi sistem Jaringan. Tujuan dilakukan penelitian ini yaitu mengembangkan e-modul dengan pendekatan STEAM berbasis sigil software dan mengetahui kevalidan, kepraktisan dan kelayakan terhadap e-modul yang dikembangkan. Jenis penelitian ini adalah penelitian pengembangan atau Research and Development (R\&D) dengan menggunakan model pengembangan 4D yang terdiri dari 4 tahapan yaitu define, design, develop dan disseminate. Namun penelitian ini hanya sampai pada tahap develop dikarenakan keterbatasan waktu serta situasi dan kondisi pandemi covid-19 saat ini. Penelitian ini bertempat di SMK Kosgoro Nganjuk dengan subjek penelitian adalah peserta didik kelas XI TKJ. Objek penelitian ini adalah e-modul dengan materi DNS server menggunakan pendekatan STEAM berbasis sigil software. Hasil dari penelitian ini diperoleh hasil validasi ahli materi sebesar $86 \%$ dan hasil validasi ahli media sebesar 92\% dengan kategori "sangat valid". Sedangkan hasil uji coba pengembangan yaitu uji coba kelompok kecil sebanyak 10 responden diperoleh hasil sebesar $84 \%$ dan uji coba kelompok besar sebanyak 28 responden diperoleh hasil sebesar 82\% dengan kategori "sangat praktis". Simpulan dari penelitian ini yaitu e-modul yang dikembangkan layak digunakan sebagai salah satu bahan ajar yang dapat digunakan dalam kegiatan pembelajaran.
\end{abstract}

Kata Kunci: E-Modul, Pendekatan STEAM, Sigil Software, Model 4D, DNS Server.

\begin{abstract}
The use of teaching materials is one of the important factors so that learning activities can run well. Educators are required to be able to innovate in the learning process in accordance with the times in the industrial era 4.0. In learning activities, of course, it requires teaching materials as a reference so that learning can run well. One of the problems encountered at SMK Kosgoro Nganjuk is the absence of teaching materials in the form of emodules and the difficulty of students finding references on the internet related to the subject of Network System Administration. The purpose of this research is to develop an e-module with a STEAM approach based on sigil software and to determine the validity, practicality and feasibility of the developed e-module. This type of research is research development or Research and Development $(R \& D)$ using a $4 D$ development model consisting of 4 stages, namely define, design, develop and disseminate. However, this research has only reached the development stage due to time constraints and the current situation and condition of the COVID-19 pandemic. This research took place at SMK Kosgoro Nganjuk with the research subjects being students of class XI TKJ. The object of this research is an e-module with DNS server material using a STEAM approach based on sigil software. The results of this study obtained the results of material expert validation by $86 \%$ and the results of media expert validation by $92 \%$ with the "very valid" category. While the results of the development trial, namely the small group trial of 10 respondents, the results were $84 \%$ and the large group trial of 28 respondents obtained the results of $82 \%$ in
\end{abstract}


the "very practical" category. The conclusion of this research is that the developed e-module is suitable to be used as one of the teaching materials that can be used in learning activities.

Keywords: E-Module, STEAM Approach, Sigil Software, 4D Model, DNS Server 


\section{PENDAHULUAN}

Adanya pandemi covid-19 atau virus corona sejak akhir 2019 yang pertama kali terjadi di Wuhan Cina telah menyebar di beberapa negara termasuk Indonesia. Dilansir dalam berita (News.detik.com,2020) Indonesia pertama kali mengkonfirmasi adanya kasus covid-19 pada awal Maret yang diumumkan oleh Bapak Presiden Jokowi dan hingga saat ini telah menyebar di 34 provinsi. Covid-19 telah mengubah tatanan dunia dalam waktu singkat salah satunya adalah perubahan sosial yang tidak direncanakan dan perubahan dalam dunia pendidikan yang hingga kini masih sangat dirasakan. Salah satu yang sangat terlihat dalam dunia pendidikan di Indonesia adalah perubahan proses pembelajaran baik di sekolah maupun perguruan tinggi terpaksa ditutup dan mengubahnya menjadi pembelajaran secara daring (dalam jaringan) guna untuk memutus rantai penyebaran covid-19. Hal ini seiring dengan kemajuan teknologi, pemanfaatan teknologi menjadi suatu keharusan sebagai solusi agar pembelajaran tetap berjalan di tengah pandemi covid-19. Kehadiran teknologi dapat dimanfaatkan untuk meningkatkan kualitas pendidikan yang merupakan kunci untuk meningkatkan kualitas sumber daya manusia dan membawa Indonesia menjadi bangsa yang unggul dalam menghadapi era revolusi industri 4.0 .

Era Revolusi Industri 4.0 ditandai dengan pesatnya kemajuan ilmu pengetahuan dan teknologi. Penelitian Global Education Census menunjukkan bahwa pelajar Indonesia termasuk pengguna teknologi tertinggi di dunia di bidang pendidikan (Report, 2018) . Sebesar $40 \%$ pengguna ruang IT/komputer di sekolah adalah siswa Indonesia yaitu menduduki peringkat tertinggi secara global. Kemudian, $67 \%$ sepertiga siswa di Indonesia menggunakan ponsel dalam pembelajaran kelas dan $81 \%$ lebih sering untuk mengerjakan tugas sekolah.

Sejalan dengan penggunaan teknologi yang sangat pesat guru dituntut harus lebih inovatif dalam proses pembelajaran. Hal ini sesuai dengan Peraturan Pemerintah Nomor 32 tahun (2013) tentang perubahan atas Peraturan Pemerintah Nomor 19 tahun 2005 tentang Standar Nasional Pendidikan bahwa proses pembelajaran pada satuan pendidikan diselenggarakan secara interaktif, inspiratif, menyenangkan, menantang, memotivasi peserta didik untuk berpartisipasi aktif, serta memberikan ruang yang cukup bagi prakarsa, kreativitas, dan kemandirian sesuai dengan bakat, minat, dan perkembangan fisik serta psikologis peserta didik. Bahan ajar merupakan salah satu elemen penting dalam pembelajaran. Bahan ajar merupakan segala bentuk bahan yang dapat digunakan guru dalam menunjang proses pembelajaran dan membantu memudahkan siswa dalam memahami suatu materi pembelajaran.

Berdasarkan Peraturan Menteri Pendidikan dan Kebudayaan No. 34 Tahun (2018) tentang Standar Nasional Pendidikan SMK/MAK dijelaskan bahwa SMK/MAK merupakan bagian dari sistem pendidikan nasional yang memiliki tujuan pendidikan kejuruan yaitu menghasilkan tenaga kerja terampil yang memiliki kemampuan sesuai dengan tuntutan kebutuhan dunia usaha/industri, serta mampu mengembangkan potensi dirinya dalam mengadopsi dan beradaptasi dengan perkembangan ilmu pengetahuan, teknologi, dan seni. Berdasarkan uraian tersebut, pembelajaran di sekolah diharapkan mampu mengembangkan siswa sesuai tuntutan pembelajaran abad 21.

Salah satu pendekatan yang memiliki karakteristik untuk menjawab tuntutan pembelajaran abad 21 adalah pembelajaran berbasis STEAM (Science, Technology, Engineering, Arts, and Mathematics). Menurut (Nurhikmayati, 2019) menyatakan STEAM sebagai sebuah pendekatan pembelajaran yang merupakan sarana bagi peserta didik untuk menciptakan ide atau gagasan pokok berbasis sains dan teknologi melalui kegiatan berpikir dan bereksplorasi dalam memecahkan masalah berdasarkan pada lima disiplin ilmu yang terintegrasi. Pembelajaran di SMK Kosgoro Nganjuk pada mata pelajaran Administrasi Sistem Jaringan menuntut siswa untuk aktif dalam pembelajaran. Siswa perlu mengeksplorasi materi-materi tentang layanan server secara mandiri mengingat kondisi saat ini yang tidak memungkinkan siswa untuk tetap melaksanakan praktek di Laboratorium sekolah secara berkelanjutan dikarenakan sistem pembelajaran tatap muka dilaksanakan secara bergantian. Hal ini 
menjadi tantangan tersendiri bagi pendidik karena pada materi ini siswa tidak hanya dituntut untuk bisa mengikuti langkah-langkah saat praktek namun juga pemahaman siswa tentang cara kerja layanan server. Salah satu alternatif yang dapat memudahkan siswa untuk belajar mandiri adalah penggunaan modul digital dengan pendekatan STEAM. Hal ini juga didukung oleh minatnya pelajar masa kini terhadap penggunaan smartphone sehingga dapat dimanfaatkan keberadaannya untuk menunjang belajar dengan adanya e-modul yang dapat diakses melalui komputer maupun android.

Ada berbagai macam aplikasi penyusun modul elektronik salah satunya yang saat ini adanya format yang didukung secara luas adalah format epub. Electronic publication (EPub) merupakan salah satu format buku digital yang disepakati oleh International Digital Publishing Forum (IDPF) pada Oktober 2011. EPub menggantikan peran Open eBook sebagai format buku terbuka. EPub terdiri atas file multimedia, html5, css, xhtml, xml yang dikemas dalam satu file. Salah satu aplikasi yang digunakan untuk menyusun buku digital dengan format ePub adalah sigil software. Menurut (Aisy et al., 2020) menyatakan sigil software adalah format EPUB dengan kelebihan yang tidak dimiliki oleh format lainnya seperti PDF yakni tersedianya perintah yang digunakan untuk penyisipan file audio dan video. Selain itu e-modul dengan format epub ini juga bersifat friendly dan support terhadap banyak perangkat seperti perangkat komputer, android dan perangkat lainnya. Oleh karena itu diharapkan pengembangan e-modul ini mempunyai keterbaruan yaitu adanya tampilan video dan link tautan untuk menambah wawasan dan e-modul lebih menarik.

Adapun penelitian yang relevan dengan penelitian ini yaitu penelitian yang dilakukan oleh (Luthfiyatul Hasanah, 2019) dengan judul "Pengembangan Modul Bioteknologi Berbasis STEAM (Science, Technology, Engineering, Arts And Mathematics) Dilengkapi Animasi Flash Untuk Pembelajaran Biologi Di SMA/MA. Pada penelitian ini dilatarbelakangi oleh permasalahan pembelajaran bioteknologi erat kaitannya dengan bahan ajar sehingga diperlukan modul sebagai penunjang belajar. Modul bioteknologi yang dikembangkan memperoleh skor kelayakan $89.85 \%$ dengan kategori sangat valid, skor rata-rata respon siswa mendapatkan nilai 81 dan dengan kategori praktis. Dengan demikian modul bioteknologi dengan pendekatan STEAM tersebut dinyatakan valid, praktis, serta layak digunakan.

Selanjutnya penelitian kedua oleh (Aji \& Widjanarko, 2016) dengan penelitian yang berjudul Pengembangan Media Pembelajaran Berbasis Buku Digital Electronic Publication (Epub). Modul yang dikembangkan dengan format ePub memperoleh hasil validasi oleh ahli materi sebesar $89,7 \%$ dan ahli media $86,80 \%$ dengan kategori sangat baik. Dengan demikian media pembelajaran yang dikembangkan dinyatakan valid dan layak digunakan.

Selanjutnya penelitian ketiga oleh (Sofia et al., 2020) dengan judul "The validity and effectivity of learning using STEAM module with biotechnology game". Penelitian ini bertujuan untuk mendeskripsikan modul sains yang dibangun berdasarkan Sains, Teknologi, Teknik, Seni dan Matematika (STEAM) dilengkapi dengan permainan bioteknologi untuk pembelajaran sains di Sekolah Menengah Pertama (SMP). Penelitian dan Pengembangan (R\&D) ini dikembangkan dengan menggunakan model 4D (Thiagarajan). Hasil validasi para validator dan pengguna sebesar 87,17 dengan kategori (sangat valid). Oleh karena itu modul yang dikembangkan adalah valid dan dapat dapat menjadi salah satu alternatif untuk memenuhi kebutuhan tersebut kebutuhan belajar sains.

Penelitian keempat oleh (Kim \& Chae, 2016) dengan judul "The Development and Application of a STEAM Program Based on Traditional Korean Culture". Penelitian ini bertujuan untuk mengembangkan program STEAM dalam konteks pengajaran dan mempelajari alat musik tradisional Korea dan menerapkannya di sekolah menengah kelas untuk menentukan efektivitas program. Hasil utama dari program STEAM yang dikembangkan adalah agar siswa dapat mengembangkan pemahaman yang kuat tentang prinsip ilmiah serta mengembangkan kreativitas mereka dan memanfaatkan emosi mereka dengan menjelajahi keindahan budaya tradisional Korea, seperti yang terlihat di danso. Secara keseluruhan, dapat disimpulkan bahwa program STEAM meningkatkan kreativitas sekaligus 
memaksimalkan minat dan motivasi dalam ilmu yang membantu meningkatkan daya saing nasional di bidang ilmu pengetahuan. Dengan demikian STEAM cenderung menumbuhkan literasi STEAM melalui konvergensi ilmu pengetahuan, teknologi dan seni dengan meningkatkan kemampuan pemecahan masalah secara kreatif.

\section{METODE PENELITIAN}

Jenis penelitian yang digunakan pada penelitian ini adalah penelitian pengembangan atau Research and Development $(R \& D)$ dengan model pengembangan 4D. Model pengembangan 4D ini memiliki empat tahapan diantaranya define (pendefinisian), design (perancangan), development (pengembangan), dan dissemination (penyebarluasan). Gambar 1 adalah diagram alur pengembangan e-modul yang peneliti tempuh berdasarkan model pengembangan 4D :

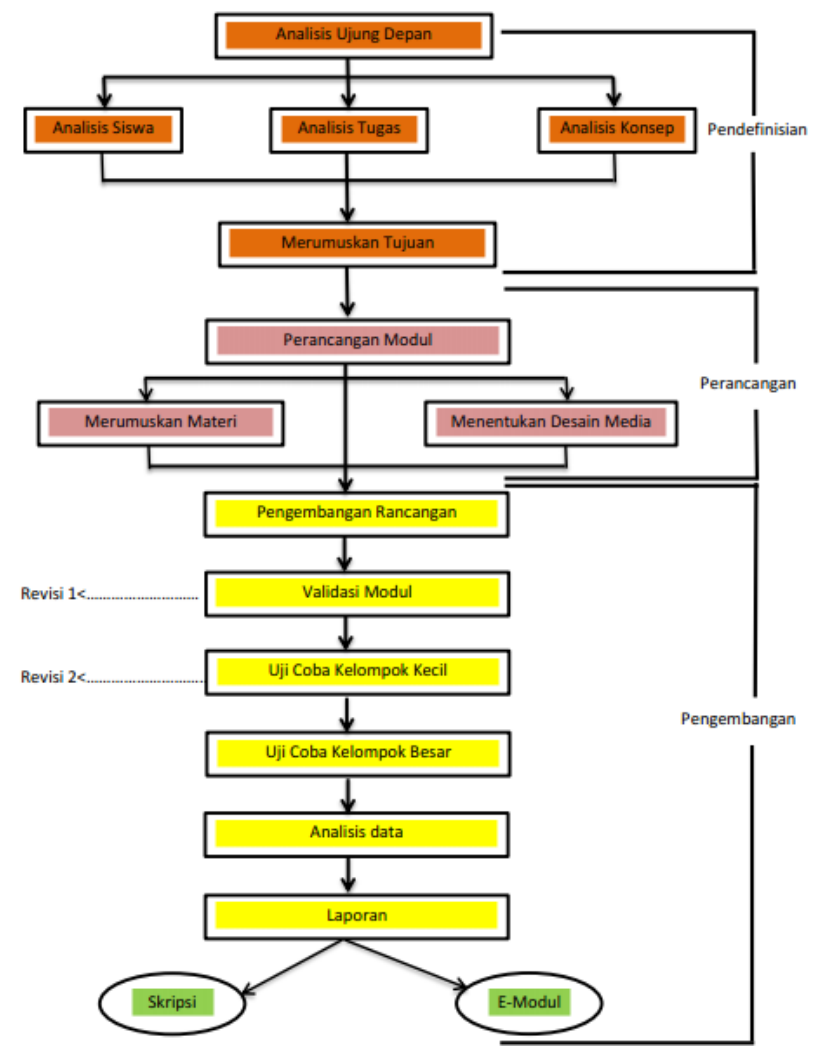

Gambar 1. Diagram alur pengembangan e-modul yang mengadopsi Model 4D

\section{Define (Pendefinisian)}

Define (pendefinisian) merupakan tahapan pertama dalam model pengembangan 4D yaitu menjelaskan syarat-syarat dalam mengembangkan sebuah produk e-modul. Terdapat lima tahapan dalam tahap pendefinisian diantaranya analisis ujung depan (front end analysis), analisis siswa (learner analysis), analisis tugas (task analysis), analisis konsep (concept analysis), dan perumusan tujuan pembelajaran specifying instructional objectives. Berikut tahapan yang dilakukan peneliti pada tahap pendefinisian yaitu :

a. Analisis Ujung Depan (Front End Analysis)

Tahap ini bertujuan untuk menemukan dan menetapkan masalah dasar dalam proses pembelajaran mata pelajaran Administrasi Sistem Jaringan sehingga peneliti dapat menentukan langkah pengembangan suatu produk e-modul yang sesuai dengan kebutuhan. Pada tahap ini yaitu dilakukan proses menganalisis atau studi literatur terkait dengan pengembangan e-modul sebagai bahan ajar dan dilakukan wawancara dengan peserta didik dan guru mata pelajaran Administrasi Sistem Jaringan dengan tujuan untuk mengetahui permasalahan-permasalahan di 
lapangan sehubungan dengan kegiatan pembelajaran di kelas khususnya mata pelajaran Administrasi Sistem Jaringan baik secara langsung maupun tidak langsung.

b. Analisis Siswa (Learner Analysis)

Pada tahap ini, dalam kaitannya dengan mengembangkan sebuah bahan ajar, karakteristik peserta didik perlu diketahui untuk menyusun bahan ajar yang sesuai dengan kemampuan akademiknya misalnya tingkat pendidikan siswa yang masih rendah, kemampuan, minat baca, latar belakang pengalaman dll (Mulyatiningsih, 2019:196).

c. Analisis Tugas (Task Analysis)

Pada tahap ini dilakukan analisis tugas-tugas apa saja yang akan diberikan kepada siswa dalam sebuah e-modul yang akan dikembangkan baik tugas secara individu maupun kelompok. Identifikasi tugas siswa dilakukan dengan melihat kompetensi dasar pembelajaran yang akan dikembangkan yaitu pada materi DNS Server. E-modul ini akan dikembangakan menggunakan sebuah pendekatan sehingga tugas-tugas yang akan diberikan berdasarkan pendekatan yang digunakan yaitu pendekatan STEAM (Science, Technology, Engineering, Arts, and Mathematics). Namun pada e-modul yang akan dikembangkan tidak semua tugas menerapkan pendekatan STEAM seperti soal pilihan ganda dan essay.

d. Analisis Konsep (Concept Analysis)

Analisis konsep dilakukan untuk mengidentifikasi materi utama yang perlu diajarkan, mengumpulkan dan memilih materi yang relevan dan menyusunnya kembali secara sistematis (Mulyatiningsih, 2019:197). Konsep e-modul yang akan dikembangkan adalah menggunakan pendekatan STEAM pada tugas yang diberikan serta e-modul secara keseluruhan dibuat dengan memuat lima disiplin ilmu pada setiap kegiatan pembelajaran. Peneliti akan mencari dan mengumpulkan sumber-sumber materi yang relevan untuk disusun kembali secara sistematis. Konsep awal yang akan diambil adalah e-modul yang berpusat pada siswa yang dapat memfasilitasi kemampuan siswa dalam pemecahan masalah.

e. Perumusan Tujuan Pembelajaran (Specifying Instructional Objectives)

Tahap ini dilakukan perumusan tujuan pembelajaran berdasarkan uraian indikator dari kompetensi dasar berdasarkan silabus SMK mata pelajaran Administrasi Sistem Jaringan kelas XI TKJ.

\section{Design (Perancangan)}

Tahapan ini dilakukan perancangan e-modul berdasarkan hasil yang didapat dari tahap analisis yaitu:

a. Merumuskan materi

Penyusunan materi dilakukan berdasarkan silabus yang digunakan sekolah. Setelah itu dilakukan tahap menyusun materi-materi apa saja yang dimuat ke dalam $e$-modul. Selanjutnya e-modul dikembangkan dengan menggunakan bantuan aplikasi Sigil.

b. Menentukan desain media

Penentuan desain ini diantaranya desain cover atau sampul e-modul, pembuatan video pendukung materi serta kerangka e-modul sesuai dengan panduan penyusunan e-modul.

c. Kerangka E-Modul

Pengembangan e-modul ini disusun menggunakan kerangka e-modul berdasarkan panduan praktis penyusunan e-modul pembelajaran tahun 2017.

\section{Development (Pengembangan)}

Produk pendidikan yang dikembangkan peneliti berupa e-modul dengan pendekatan STEAM berbasis sigil software dengan materi tentang DNS Server. Materi yang akan disusun berdasarkan silabus SMK pada mata pelajaran terkait. Langkah-langkah pada tahapan ini diantaranya : 
a. Pengembangan rancangan

Pengembangan rancangan yang dimaksud pada tahapan ini adalah proses mengembangkan e-modul dengan materi DNS Server untuk SMK TKJ kelas XI. Produk yang dihasilkan dari penelitian pengembangan ini dibuat dengan menggunakan beberapa bantuan aplikasi diantaranya :

1) Ms. Word untuk merancang dan menyusun draft e-modul.

2) Corel Draw untuk merancang dan mendesain sampul e-modul dan beberapa icon untuk judul bab dan sub bab e-modul.

3) Sigil Software merupakan aplikasi utama yang digunakan peneliti untuk mengubah format e-modul ke dalam format epub, menyisipkan video ataupun link tautan referensi dll.

b. Validasi Ahli

Setelah e-modul dibuat selanjutnya e-modul divalidasi oleh para validator. Validasi ini bertujuan untuk mengetahui kevalidan dan kelayakan e-modul yang telah dikembangkan. Setelah dilakukan validasi oleh para validator, maka akan dilakukan revisi berdasarkan saran, kritik serta masukan dari para validator.

c. Uji Coba Pengembangan

Bahan ajar e-modul yang telah selesai direvisi berdasarkan saran dari para ahli materi dan media, kemudian diuji cobakan pada siswa. Uji coba dilakukan untuk mengetahui kepraktisan, daya tarik serta kebergunaan bahan ajar e-modul berbasis sigil software. Uji coba produk dilakukan dengan 2 tahap yaitu uji coba kelompok kecil dan uji coba kelompok besar. Menurut (Arikunto, 2013:254) menyatakan bahwa jumlah subjek uji coba kelompok kecil berjumlah 4-14 siswa dan uji coba kelompok besar berjumlah 15-50 siswa.

1) Uji Kelompok Kecil

Produk e-modul akan diuji cobakan kepada 10 responden untuk mengetahui respon peserta didik dan memberikan penilaian terhadap kualitas produk yang dikembangkan.

2) Uji Coba Kelompok Besar

Uji coba kelompok besar merupakan tahap terakhir dari evaluasi produk yang perlu dilakukan apabila masih terdapat perbaikan. Pada tahap ini tentunya produk yang dikembangkan atau dibuat sudah mendekati sempurna setelah melalui tahap perbaikan berdasarkan uji coba kelompok kecil tersebut. Pada uji lapangan pada 28 peserta didik dengan berbagai karakteristik sesuai dengan karakteristik populasi sasaran. Dari hasil uji coba produk, apabila respon peserta didik mengatakan bahwa produk ini baik dan praktis, maka dapat dikatakan bahwa bahan ajar telah selesai dikembangkan, sehingga menghasilkan produk akhir. Namun apabila produk belum sempurna maka hasil uji coba ini dijadikan bahan perbaikan dan penyempurnaan bahan ajar yang dibuat, sehingga dapat menghasilkan produk akhir yang dapat digunakan di sekolah.

Fokus penelitian ini adalah untuk melihat kelayakan produk berdasarkan kevalidan dan kepraktisan modul yang dibuat.

a. Tahap Validitas

Analisis validitas pada pengembangan e-modul ini adalah analisis pada setiap angket validasi para ahli. Validator akan memberikan penilaian saran, kritik maupun masukan mengenai apa saja yang harus direvisi terkait produk yang peneliti kembangkan. Adapun perhitungan validasi berdasarkan (Isharyadi \& Ario, 2019) dihitung menggunakan persamaan (1) berikut :

Persentase Jawaban $=\frac{\sum \text { skor yang diperoleh } \times 100 \%}{\sum \text { skor maksimal }}$ 
Tabel 1 Kriteria Penilaian Validitas Instrumen

\begin{tabular}{cl}
\hline Kriteria Validitas & \multicolumn{1}{c}{ Tingkat Validitas } \\
\hline $85,01 \%-100,00 \%$ & Sangat valid atau dapat digunakan tanpa revisi. \\
\hline $70,01 \%-85,00 \%$ & Cukup valid atau dapat digunakan namun perlu revisi kecil. \\
\hline $50,01 \%-70,00 \%$ & Kurang valid, disarankan tidak dipergunakan karena perlu revisi besar. \\
\hline $01,00 \%-50,00 \%$ & Tidak valid, atau tidak boleh dipergunakan. \\
\hline
\end{tabular}

Sumber:(Sa'dun Akbar, 2017:41)

b. Tahap Kepraktisan

Analisis kepraktisan diperoleh dari hasil uji coba produk kepada siswa kelas XI. Dalam hal ini uji coba yang dimaksud adalah untuk mengetahui kepraktisan, daya tarik serta kebergunaan apakah produk e-modul dapat membantu dan mempermudah siswa dalam belajar khususnya materi tentang DNS Server. Menurut (Isharyadi \& Ario, 2019) analisis uji kepraktisan modul dilakukan dengan memberikan angket bagi peserta didik, dengan penentuan prosentase menggunakan persamaan (2) yang seluruh item berdasarkan kriteria pada Tabel 2:

Persentase Jawaban $=\frac{\sum \text { skor yang diperoleh x } 100 \%}{\sum \text { skor maksimal }}$

Tabel 2 Kriteria Kepraktisan E-Modul

\begin{tabular}{cc}
\hline Kriteria Kepraktisan & Tingkat Kepraktisan \\
\hline $81 \%-100 \%$ & Sangat praktis \\
\hline $61 \%-80 \%$ & Praktis \\
\hline $41 \%-60 \%$ & Cukup Praktis \\
\hline $21 \%-40 \%$ & Kurang Praktis \\
\hline $0 \%-20 \%$ & Tidak Praktis \\
\hline & Sumber: Diadaptasi dari (Isharyadi \& Ario, 2019)
\end{tabular}

\section{HASIL DAN PEMBAHASAN}

Hasil dari penelitian ini yaitu menghasilkan bahan ajar e-modul dengan menggunakan sigil software pada materi DNS Server kelas XI TKJ. E-modul ini akan dikembangkan menggunakan sebuah pendekatan sehingga tugas-tugas yang akan diberikan berdasarkan pendekatan yang digunakan yaitu pendekatan STEAM (Science, Technology, Engineering, Arts, and Mathematics) pada setiap kegiatan pembelajaran. E-modul ini dapat diakses melalui android dengan bantuan aplikasi supreader serta aplikasi readium untuk PC atau laptop. Gambar 2 menunjukkan tampilan e-modul.

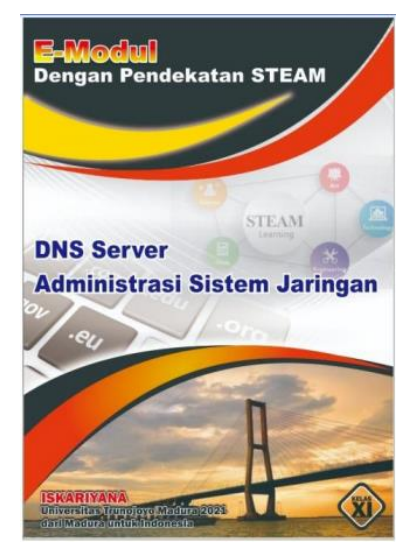

Gambar 2. Cover E-Modul

46 | Pengembangan E-Modul Dengan Pendekatan STEAM Berbasis Sigil Software Mata Pelajaran Administ... 


\section{a. Validasi Ahli}

Tahap validasi merupakan tahap menilai yang dilakukan oleh para ahli terkait apakah rancangan produk e-modul dinyatakan valid dan layak digunakan.

1) Validasi Ahli Materi

Hasil dari validasi bahan ajar berupa e-modul, validator 1 memberikan nilai 72 dengan persentase $80 \%$ dan validator 2 memberikan nilai 83 dengan persentase 92\%. Dari total nilai yang diperoleh dari validator 1 dan validator 2 maka didapatkan rata-rata persentase dari kedua validator sebesar $86 \%$ dan jika dikonversikan berdasarkan tabel persentase kevalidan, e-modul yang dikembangkan dengan menggunakan pendekatan STEAM berbasi sigil software sangat valid dan tidak perlu dilakukan revisi sehingga e-modul layak untuk digunakan

2) Validasi Ahli Media

Hasil dari validasi bahan ajar berupa e-modul, validator 1 memberikan nilai 97 dengan persentase $97 \%$ dan validator 2 memberikan nilai 87 dengan prosentase $87 \%$. Dari total nilai yang diperoleh dari validator 1 dan validator 2 maka didapatkan rata-rata persentase dari kedua validator sebesar $92 \%$ dan jika dikonversikan berdasarkan tabel persentase kevalidan, e-modul yang dikembangkan dengan menggunakan pendekatan STEAM berbasi sigil software sangat valid sehingga layak untuk digunakan.

\section{b. Uji Coba Pengembangan}

Uji coba pengembangan ini dilakukan untuk mengetahui kepraktisan, daya tarik serta kebergunaan apakah produk e-modul dapat membantu dan mempermudah siswa dalam belajar khususnya materi tentang DNS Server. Uji coba dilakukan dua tahap antara lain uji coba kelompok kecil kepada 10 siswa dan uji coba kelompok besar kepada 28 siswa.

1) Uji Coba Kelompok Kecil

Siswa dalam uji kelompok kecil ini melihat e-modul yang diberikan dan di akhir uji coba produk kemudian siswa diberi angket untuk menilai e-modul yang peneliti kembangkan. Hasil uji coba kelompok kecil dapat dilihat pada Tabel 3 berikut.

Tabel 3. Hasil Uji Coba Kelompok Kecil

\begin{tabular}{ccccc}
\hline No & Nama & Jumlah Skor & $\begin{array}{c}\text { Tingkat } \\
\text { Kepraktisan }\end{array}$ & Kategori \\
\hline $\mathbf{1 .}$ & Res1 & 96 & $84 \%$ & Sangat Praktis \\
\hline $\mathbf{2 .}$ & Res2 & 98 & $85 \%$ & Sangat Praktis \\
\hline $\mathbf{3 .}$ & Res3 & 104 & $90 \%$ & Sangat Praktis \\
\hline $\mathbf{4 .}$ & Res4 & 102 & $89 \%$ & Sangat Praktis \\
\hline $\mathbf{5 .}$ & Res5 & 95 & $83 \%$ & Sangat Praktis \\
\hline $\mathbf{6 .}$ & Res6 & 108 & $94 \%$ & Sangat Praktis \\
\hline $\mathbf{7 .}$ & Res7 & 84 & $73 \%$ & Praktis \\
\hline $\mathbf{8 .}$ & Res8 & 92 & $80 \%$ & Praktis \\
\hline 9. & Res9 & 85 & $74 \%$ & Praktis \\
\hline $\mathbf{1 0}$ & Res10 & 101 & $88 \%$ & Sangat Praktis \\
\hline Rata-rata kepraktisan & & $\mathbf{8 4 \%}$ & & Sangat Praktis \\
\hline
\end{tabular}

Berdasarkan tabel di atas dapat diketahui bahwa hasil dari uji coba kelompok kecil bahan ajar berupa e-modul, persentase dari total skor yang diperoleh dari 10 responden didapatkan rata-rata sebesar $84 \%$ dan jika dikonversikan berdasarkan tabel persentase kepraktisan, e-modul yang dikembangkan dengan menggunakan pendekatan STEAM berbasi sigil software sangat praktis untuk digunakan.

2) Uji Coba Kelompok Besar

Siswa dalam uji kelompok besar ini melihat e-modul yang diberikan dan di akhir uji coba produk 
kemudian peserta diberi angket untuk menilai e modul yang peneliti kembangkan. Uji coba kelompok besar ini merupakan tahap akhir untuk menilai kepraktisan produk. Hasil uji coba kelompok besar dapat dilihat pada Tabel 4 berikut.

Tabel 4. Hasil Uji Coba Kelompok Besar

\begin{tabular}{|c|c|c|c|c|}
\hline No & Nama Siswa & Total Skor & $\begin{array}{c}\text { Tingkat } \\
\text { Kepraktisan }\end{array}$ & Kategori \\
\hline 1. & Res1 & 93 & $81 \%$ & Sangat Praktis \\
\hline 2. & Res2 & 97 & $84 \%$ & Sangat Praktis \\
\hline 3. & Res3 & 85 & $74 \%$ & Praktis \\
\hline 4. & Res4 & 89 & $77 \%$ & Praktis \\
\hline 5. & Res5 & 104 & $90 \%$ & Sangat Praktis \\
\hline 6. & Res6 & 91 & $88 \%$ & Sangat Praktis \\
\hline 7. & Res7 & 97 & $84 \%$ & Sangat Praktis \\
\hline 8. & Res8 & 98 & $85 \%$ & Sangat Praktis \\
\hline 9. & Res9 & 99 & $86 \%$ & Sangat Praktis \\
\hline 10. & Res10 & 85 & $74 \%$ & Praktis \\
\hline 11. & Res11 & 92 & $80 \%$ & Praktis \\
\hline 12. & Res12 & 93 & $81 \%$ & Sangat Praktis \\
\hline 13. & Res13 & 96 & $84 \%$ & Sangat Praktis \\
\hline 14. & Res14 & 98 & $85 \%$ & Sangat Praktis \\
\hline 15. & Res15 & 89 & $77 \%$ & Praktis \\
\hline 16. & Res16 & 93 & $81 \%$ & Sangat Praktis \\
\hline 17. & Res17 & 92 & $80 \%$ & Praktis \\
\hline 18. & Res18 & 105 & $91 \%$ & Sangat Praktis \\
\hline 19. & Res19 & 84 & $73 \%$ & Praktis \\
\hline 20. & Res20 & 96 & $83 \%$ & Sangat Praktis \\
\hline 21. & Res21 & 115 & $100 \%$ & Sangat Praktis \\
\hline 22. & Res22 & 89 & $77 \%$ & Praktis \\
\hline 23. & Res23 & 108 & $94 \%$ & Sangat Praktis \\
\hline 24. & Res24 & 101 & $88 \%$ & Sangat Praktis \\
\hline 25. & Res 25 & 90 & $78 \%$ & Praktis \\
\hline 26. & Res26 & 72 & $63 \%$ & Praktis \\
\hline 27. & Res27 & 93 & $81 \%$ & Sangat Praktis \\
\hline 28. & Res 28 & 93 & $81 \%$ & Sangat Praktis \\
\hline \multicolumn{2}{|c|}{ Rata-rata kepraktisan } & \multicolumn{2}{|c|}{$82 \%$} & Sangat Praktis \\
\hline
\end{tabular}

Berdasarkan tabel di atas dapat diketahui bahwa hasil dari uji coba kelompok besar bahan ajar berupa emodul, persentase yang diperoleh dari 28 responden didapatkan rata-rata sebesar $82 \%$ dan jika dikonversikan berdasarkan tabel persentase kepraktisan, e-modul yang dikembangkan dengan menggunakan pendekatan STEAM berbasis sigil software sangat praktis untuk digunakan.

\section{KESIMPULAN}

Berdasarkan data yang diperoleh didapatkan hasil penilaian kelayakan oleh ahli materi, ahli media dan hasil uji coba pengembangan. Hasil penilaian ahli materi didapatkan rata-rata persentase $86 \%$ dengan kategori sangat valid dan layak digunakan tanpa revisi. Hasil penilaian ahli media didapatkan rata-rata persentase $92 \%$ dengan kategori sangat valid. Hasil penilaian uji coba pengguna yaitu uji coba kelompok kecil yang dilaksanakan pada Selasa, 27 April 2021 di SMK Kosgoro Nganjuk yang diikuti oleh 10 peserta didik mendapatkan rata-rata persentase $84 \%$ dengan kategori sangat praktis sedangkan hasil uji coba kelompok besar yang dilaksanakan pada Kamis, 29 April 2021 di SMK Kosgoro Nganjuk yang diikuti oleh 28 peserta didik mendapatkan rata-rata persentase $82 \%$ dengan kategori sangat praktis. Hal ini menunjukkan bahwa e-modul dengan pendekatan STEAM berbasis sigil software layak digunakan sebagai bahan ajar. 
Berdasarkan hasil penelitian dan pembahasan, maka saran dari peneliti untuk pengembangan emodul selanjutnya yaitu :

1. E-modul hanya memuat satu kompetensi dasar dengan pembahasan 1 pokok materi yang dibagi menjadi 3 kegiatan pembelajaran, maka diperlukan penelitian secara berkelanjutan mengenai pengembangan e-modul ini sebagai penyempurnaan e-modul pembelajaran selanjutnya.

2. E-modul ini hanya sampai tahap pengembangan sehingga perlu dilakukan penyebaran produk untuk penelitian dan pengembangan selanjutnya.

3. Perlu dilakukan pengujian efektivitas dari e-modul yang dikembangkan terhadap pencapaian kompetensi siswa.

\section{DAFTAR PUSTAKA}

Aisy, D. R., Farida, F., \& Andriani, S. (2020). Pengembangan E-Modul Berbantuan Sigil Software Dengan Pendekatan Saintifik Pada Materi Sistem Persamaan Linier Dua Variabel (Spldv). Edu Sains Jurnal Pendidikan Sains \& Matematika, 8(1), 61-71. https://doi.org/10.23971/eds.v8i1.1499

Aji, M., \& Widjanarko, D. (2016). Media Development Of Learning Comprehension And Maintenance Conventional Starting System Based On Digital Book Electronic Publication (EPUB). Jurnal Pendidikan Teknik Mesin, $16(1), \quad 37-42$. https://journal.unnes.ac.id/nju/index.php/JPTM/article/view/9154/5972

Arikunto. (2013). Prosedur Penelitian Suatu Pendekatan Praktik. Rineka Cipta.

Isharyadi, R., \& Ario, M. (2019). Praktikalitas dan Efektivitas Modul Geometri Transformasi Berbantuan Geogebra bagi Mahasiswa Pendidikan Matematika. Jurnal Absis: Jurnal Pendidikan Matematika Dan Matematika, 1(2), 86-93. https://doi.org/10.30606/absis.v1i2.93

Kemendikbud. (2017). Panduan Praktis Penyusunan E-Modul. 1-57.

Kementerian Pendidikan dan Kebudayaan. (2018). Permendikbud Nomor 34 Tahun 2018 Tentang Standar Nasional Pendidikan SMK-MAK.

Kim, H., \& Chae, D. H. (2016). The development and application of a STEAM program based on traditional Korean culture. Eurasia Journal of Mathematics, Science and Technology Education, 12(7), 1925-1936. https://doi.org/10.12973/eurasia.2016.1539a

Luthfiyatul Hasanah. (2019). Pengembangan Modul Bioteknologi Berbasis STEAM (Science, Technology, Engineering, Arts and Mathematics) Dilengkapi Animasi Flash Untuk Pembelajaran Bioteknologi di SMA/MA. Tesis.

Mulyatiningsih, D. E. (2019). Metode Penelitian Terapan Bidang Pendidikan. Alfabeta.

News.detik.com. (2020). “Kapan Sebenarnya Corona Pertama Kali Masuk RI?” Tim Detikcom. 2020. https://news.detik.com/berita/d-4991485/kapan-sebenarnya-corona-pertama-kali-masuk-ri.

Nurhikmayati, I. (2019). Implementasi STEAM Dalam Pembelajaran Matematika. Didactical Mathematics, 1(2), 41-50. https://doi.org/10.31949/dmj.v1i2.1508

Peraturan Pemerintah Republik Indonesia. (2013). Peraturan Pemerintah Nomor 32 Tahun 2013 Tentang Perubahan Atas Peraturan Pemerintah Nomor 19 Tahun 2005 Tentang Standar Nasional Pendidikan. 
Sofia, H. W., Utomo, A. P., Hariyadi, S., Wahono, B., \& Narulita, E. (2020). The validity and effectivity of learning using STEAM module with biotechnology game. JPBI (Jurnal Pendidikan Biologi Indonesia), 6(1), 91-100. https://doi.org/10.22219/jpbi.v6i1.10979

Sa'dun Akbar, M. P. (2017). Instrumen Perangkat Pembelajaran. PT Remaja Rosdakarya. 